Jurnal Ilmu Pendidikan Fisika is licensed under

A Creative Commons Attribution-Non Commercial 4.0 International License.

\title{
Pengembangan Buku Petunjuk Praktikum IPA Berbasis Model Pembelajaran POE (PREDict ObSERVE Explain) PADA MATERI USAHA DAN ENERGI
}

\author{
Rin Agustia Nur Maulida1), Intan Kusumawati2), Andika Kusuma Wijaya ${ }^{2)}$ \\ 1) Program Studi Pendidikan Fisika, STKIP Singkawang \\ E-mail: rinmaulida@gmail.com \\ 2) Program Studi Pendidikan Fisika, STKIP Singkawang \\ E-mail: intankusumawati10@gmail.com \\ 2) Program Studi Pendidikan Fisika, STKIP Singkawang \\ E-mail: andikakusumawijaya1988@gmail.com
}

\begin{abstract}
Abstrak. Penelitian ini bertujuan untuk menghasilkan buku petunjuk praktikum IPA berbasis model pembelajaran POE (Predict Observe Explain) pada materi usaha dan energi kelas VIII SMP di kota Singkawang, kualitas buku petunjuk praktikum, dan respon siswa terhadap buku petunjuk praktikum. Penelitian ini menggunakan metode Research \& Development. Subjek dalam penelitain ini adalah dua orang guru IPA SMP dan 40 orang siswa kelas VIII dari SMP Negeri 8 Singkawang, serta SMP Torsina 1 Singkawang. Teknik pengumpulan data yang digunakan adalah angket untuk mengetahui penilaian kualitas dan respon dari buku petunjuk praktikum yang dibuat. Dari hasil penelitian dapat disimpulkan bahwa, (1) telah dihasilkan buku petunjuk praktikum IPA berbasis model pembelajaran POE pada materi usaha dan energi kelas VIII SMP kota Singkawang yang telah dikembangkan dengan men ggunakan model pengemban gan prosedural, y ang direvisi berdasark an masukan dari ahli materi, ahli media, dan guru, (2) kualitas buku petunjuk praktikum y ang dinilai oleh dua guru IPA kelas VIII y ang masing-masing berasal dari SMP Negeri 8 Singkawang dan SMP Torsina 1 Singkawang adalah sangat baik, dengan skor 102, sehingga buku petunjuk praktikum IPA berbasis POE, lay ak untuk digunakan oleh guru sebagai bahan ajar di sekolah, (3) kualitas buku petunjuk praktikum yang dinilai berdasarkan respon 12 or ang siswa pada uji coba skala kecil sebesar 67,66 dengan kriteria Baik (B). Sedangkan pada uji coba skala luas yang dilakukan pada 40 siswa yang berasal dari SMP Negeri 8 Singkawang dan SMP Torsina 1 Singkawang, dengan rincian 20 siswa dari SMP Negeri 8 Singkawang, 20 orang dari SMP Torsina 1 Singkawang adalah Sangat Baik (SB), dengan skor 68,20, sehingga buku petunjuk praktikum IPA berbasis POE dapat digunakan oleh siswa sebagai tambahan sumber belajar.
\end{abstract}

Kata Kunci: Pengembangan; Buku Petunjuk Praktikum IPA; POE

\section{PENDAhUluan}

Pendidikan telah menjadi suatu kebutuhan yang penting dalam kehidupan manusia. Hal ini dikarenakan peran pendidikan sangat penting untuk mensejahterakan kehidupan manusia itu sendiri. Pentingnya peran pendidikan menjadi paradigma terjadinya perubahan menuju pendidikan berbasis pengalaman. Pendidikan berbasis pengalaman merupakan bentuk pembelajaran yang dianggap dapat menunjang peningkatan kualitas pembelajaran [1]. Satu diantaranya adalah dengan penggunaan metode eksperimen (praktikum) dalam kegiatan pembelajaran, khususnya dalam pelajaran Fisika [2].
Fisika adalah cabang Ilmu Pengetahuan Alam (IPA) yang mempelajari tentang berbagai fenomena alam serta interaksi benda-benda di alam tersebut secara fisik dan mencoba merumuskannya secara matematis sehingga dapat dimengerti secara pasti oleh manusia. Jadi, IPA adalah ilmu pasti yang dapat diketahui kebenarannya oleh manusia dengan cara menggunakan rumus-rumus atau penelitian.

Penguasaan fisika tidak cukup dengan membaca saja, melainkan siswa harus menguasai konsep-konsep, dan terlibat aktif dalam proses pembelajaran baik berupa pembelajaran klasikal, maupun dalam kegiatan praktikum langsung [3]. Kegiatan praktikum ini membutuhkan sumber belajar yang menunjang keterlaksanaannya. Sumber belajar yang digunakan dapat berupa buku pelajaran, maupun Lembar 
Kerja Siswa (LKS) yang disediakan oleh sekolah. Berdasarkan observasi yang dilakukan di SMPN 8 Singkawang, ditemukan bahwa buku dan LKS yang digunakan pada proses pembelajaran masih bersifat umum. Buku dan LKS tersebut berisi materi dan kegiatan praktikum yang menggunakan bahasa prosedural umum, yang membutuhkan bantuan guru dalam memaknai kegiatan praktikum yang akan dilaksanakan. Hal ini menyebabkan siswa tidak dapat melaksanakan praktikum secara mandiri. Oleh karena itu, dibutuhkan alat bantu berupa buku petunjuk praktikum berbasis model pembelajaran POE (Predict Observe Explain).

POE merupakan model yang menggunakan tiga langkah utama dari metode ilmiah. Model pembelajaran ini me libatkan siswa secara aktif dalam penyusunan prediksi sebelum melakukan eksperimen, kemudian mengamati sepanjang eksperimen berlangsung, dan menjelaskan hasil eksperimen setelah melakukan pengamatan [4].

Buku petunjuk praktikum berbasis model pembelajaran POE dengan materi usaha dan energi yang diharapkan dapat menjadi acuan yang jelas pada kegiatan praktikum. Buku petunjuk berbasis model pe mbelajaran POE ini akan melatih siswa untuk menggunakan tiga langkah utama dari penelitian ilmiah, yaitu predict atau membuat prediksi. Siswa diminta menduga apa yang terjadi pada suatu kejadian fisika. Observe atau melakukan penelitian, siswa diminta untuk mengamati apa yang terjadi selama praktikum. Explain atau meberikan penjelasan. Siswa diminta untuk menjelaskan hasil eksperimennya, lalu menyesuaikan hasil prediksi awal dengan hasil eksperimen. Jika prediksi dengan hasil eksperimen sama, maka siswa akan semakin yakin dengan konsep yang diketahui. Sebaliknya, jika hasil pred iksi berbeda dengan hasil eksperimen mereka, siswa dapat dibimbing untuk mencari penjelasannya sehingga mengubah hasil prediksi awalnya, dan me mbenarkan prediksi yang awalnya keliru tadi. Penjelasan yang membimbing siswa untuk menemukan jawaban yang benar membuat sis wa mengetahui perubahan dari konsep yang salah menjadi konsep yang benar. Pembimbingan yang diberikan kepada siswa dapat membuat siswa belajar dari kesalahannya, dianggap dapat diingat siswa dalam jangka waktu yang panjang [4].

Selain membantu proses pembelajaran siswa di sekolah, pengembangan buku petunjuk praktikum berbasis POE ini juga mengacu pada visi dan misi STKIP Singkawang, yakni enterpreneurship. Mahasiswa STKIP Singkawang, selain diharapkan menjadi seorang Sarjana Pendidikan yang berkualitas, juga diharapkan dapat memiliki jiwa sosial enterpreneurship. Hal ini diwujudkan dengan dihasilkannya produk-produk yang dapat membantu perkembangan dunia pendidikan karena tersedianya media pembelajaran yang dapat meningkatkan keaktifan siswa. Jadi, mahasiswa harus memiliki sifat keberanian, inovatif, kreatif, dapat menghadapi tantangan hidup, serta dapat mewujudkan peluang yang ada saat itu. Tindakan atau produk yang dihasilkan tidak sematamata untuk kepentingan dirinya sendiri, tapi juga harus bermanfaat bagi lingkungan sosialnya. Dengan demikian, buku petunjuk praktikum IPA berbasis model pembelajaran POE diharapkan dapat dijadikan motivasi bagi guru untuk melakukan inovasi dalam proses pembelajaran dalam upaya meningkatkan keaktifan siswa, terutama pengembangan buku petunjuk praktikum.

Berdasarkan hal tersebut, maka dilakukan penelitian dengan tujuan untuk (1) menghasilkan buku petunjuk praktikum IPA berbasis model pembelajaran POE (Predict Observe Explain) pada materi usaha dan energi kelas VIII SMP di kota Singkawang, (2) mengetahuikualitas buku petunjuk praktikum berbasis model pembelajaran POE (Predict Observe Explain) pada materi usaha dan energi kelas VIII SMP di kota Singkawang, dan untuk (3) mengetahui respon siswa terhadap buku petunjuk praktikum IPA berbasis model pembelajaran POE (Predict Observe Explain) pada materi usaha dan energi kelas VIII SMP di kota Singkawang.

\section{METODE PENELITIAN}

Metode yang digunakan dalam penelitian ini adalah metode penelitian dan pengembangan atau R \& D (Research and Development). Metode penelitian dan pengembangan adalah metode penelitian digunakan untuk menghasilkan produk tertentu, dan menguji keefektifan produk tersebut.

Metode penelitian dan pengembangan telah banyak digunakan pada bidang-bidang ilmu alam dan teknik. Hampir semua produk teknologi diproduk dan dikembangkan melalui penelitian dan pengembangan. Untuk dapat menghasilkan produk tertentu digunakan penelitian yang bersifat analisis kebutuhan dan untuk menguji keefektifan produk tersebut supaya dapat berfungsi di masyarakat luas, maka diperlukan penelitian untuk menguji keefektifan produk tersebut. Jadi, penelitian dan pengembangan bersifat longitudinal (bertahap atau bis a multi years) [5].

Adapun desain yang digunakan dalam penelitian pengembangan ini menggunakan desain deskriptif yang dimulai dari pengumpulan referensi yang diperlukan dan mendukung dalam pembuatan buku petunjuk praktikum, merancang buku petunjuk praktikum IPA berbasis model pembelajaran POE, hingga penilaian kualitasnya.

Subjek uji coba yang melakukan penilaian kualitas produk buku petunjuk praktikum adalah dua orang guru IPA SMP di kota Singkawang, yakni dari SMP Negeri 8 kota Singkawang, dan SMP Torsina 1 kota Sing kawang, dan 20 orang siswa dari masing-masing sekolah tersebut.

Adapun data yang digunakan dalam penelitian pengembangan ini adalah sebagaiberikut.

a. Data Kualitatif

Data kualitatif dalam penelitian ini menggunakan skala Likert. Jawaban pernyataan berupa skala SB (Sangat Baik), B (Baik), C (Cukup), K (Kurang), dan SK (Sangat Kurang) diterapkan pada instrumen penilaian para ahli baik ahli materi, ahli media, dan guru IPA SMP, serta angket respon siswa.

b. Data Kuantitatif

Data kuantitatif berupa skor penilaian, yaitu: $\mathrm{SB}=5, \mathrm{~B}=$ $4, C=3, K=2$, dan $S K=1$. Sedangkan pada pernyataan negatif di lembar angket respon siswa, skor pernyataan negatif yaitu: $\mathrm{SB}=1, \mathrm{~B}=2, \mathrm{C}=3, \mathrm{~K}=4$, dan $\mathrm{SK}=5$ 


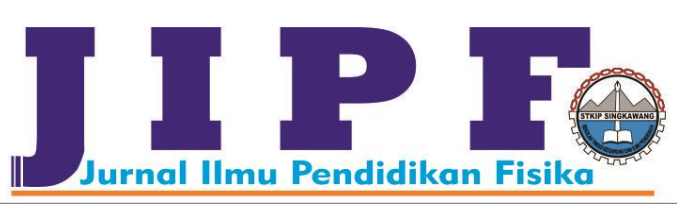

Penelitian ini menggunakan analisis data deskriptif dengan menggunakan dua variabel, yaitu variabel penyusunan buku petunjuk praktikum IPA berbasis POE. Data yang telah diperoleh, kemudian dianalis is.

Adapun proses pengembangan produk yang dilakukan meliputi tahap-tahap sebagaiberikut.

1) Analisis kurikulum dan materi

2) Pengumpulan sumber referensi

3) Tahap berikutnya adalah pembuatan buku petunjuk praktikum IPA berbasis POE.

Buku petunjuk praktikum ini akan divalidasi oleh ahli media dan ahli materi untuk mendapatkan revisi produk. Hasil revisi buku petunjuk praktikum kemudian akan dinilai kualitas nya oleh dua guru IPA SMP, sehingga didapatkan data kualitas buku petunjuk praktikum IPA berbasis POE untuk selanjutnya dianalis is.

Skor data hasil validasi oleh ahli materi, ahli media, dan penilaian kualitas buku petunjuk praktikum IPA berbasis model pe mbelajaran POE oleh guru ditentukan me lalu i angket.

Hasil validasi oleh ahli materi dan ahli media, penilaian dua orang guru IPA SMP, dan siswa yang berupa huruf kemudian diubah menjadi nilai kualitatif buku petunjuk praktikum IPA berbas is POE dengan langkah-langkah sebagaiberikut.

1) Hasil penilaian dari ah li materi, ahli media, dua guru IPA SMP sebagai Penilai, dan 40 siswa yang masih dalam bentuk huruf kemudian diubah menjadi skor dengan ketentuan seperti pada Tabel 1 sebagai berikut.
Jurnal Ilmu Pendidikan Fisika

Volume 3 Number 1 month March 2018. Page 14-19 p-ISSN: 2477-5959 e-ISSN: 2477-8451

TABEL 1

ATURAN PEMBERIAN SKOR

\begin{tabular}{cc}
\hline Keterangan & Skor \\
\hline SB (Sangat Baik) & 5 \\
B (Baik) & 4 \\
C (Cukup) & 3 \\
K (Kurang) & 2 \\
SK (Sangat Kurang) & 1 \\
\hline
\end{tabular}

2) Setelah data terkumpul, skor rata-rata dari tiap aspek penilaian dihitung dengan persamaan sebagai berikut.

$$
\bar{X}=\frac{\sum X}{N}
$$

Keterangan:

$$
\begin{array}{ll}
\bar{X} & =\text { Skor rata-rata tiap aspek } \\
N & =\text { Jumlah penilai } \\
\sum X & =\text { Jumlah skor tiap aspek }
\end{array}
$$

3) Mengubah skor rata-rata tiap aspek yang berupa data kuantitatif menjadi data kualitatif sesuai dengan kriteria kategori penilaian tiap aspek dengan ketentuan yang dijabarkan pada Tabel 2 sebagaiberikut [6].

TABEL 2

KRITERIA KATEGORI PENILAIAN IDEAL

\begin{tabular}{ccc}
\hline No. & Rentang Skor (i) Kuantitatif & Kategori Kualitatif \\
\hline 1. & $\bar{X}>\left(M_{i}+1,5 S B_{i}\right)$ & Sangat Baik \\
2. & $\left(M_{i}+0,5 S B_{i}\right)<\bar{X} \leq\left(M_{i}+1,5 S B_{i}\right)$ & Baik \\
3. & $\left(M_{i}-0,5 S B_{i}\right)<\bar{X} \leq\left(M_{i}+0,5 S B_{i}\right)$ & Cukup \\
4. & $\left(M-1,5 S B_{i}\right)<\bar{X} \leq\left(M_{i}-0,5 S B_{i}\right)$ & Kurang \\
5. & $\bar{X} \leq\left(M_{i}-1,5 S B_{i}\right)$ & Sangat Kurang \\
\hline
\end{tabular}

Adapun rata-rata ideal dan simpangan baku ideal dirumuskan sebagai berikut.

$M_{i}=1 / 2 \mathrm{x}$ (skor maksimal ideal+skor minimal ideal)

$S B_{i}=(1 / 2 \times 1 / 3) \times$ (Skor maksimal ideal - skor minimal ideal)

Keterangan:

$M_{i}=$ Rata-rata ideal yang dapat dicari dengan menggunakan rumus sebagaiberikut.

$S B_{i}=$ Simpangan baku ideal yang dapat dicari menggunakan rumus sebagaiberikut.

Skor maksimal ideal $=\sum$ butir kriteria $\mathrm{x}$ skor tertinggi

Skor minimal ideal $=\sum$ butir kriteria $\mathrm{x}$ skor terendah
4) Menghitung skor rata-rata tiap buku petunjuk praktikum dengan menggunakan persamaan sebagai berikut.

$$
\bar{Y}=\frac{\sum Y}{N}
$$

Keterangan:

$$
\begin{array}{ll}
\bar{Y} & =\text { Skor rata-rata buku petujuk praktikum } \\
\mathrm{N} & =\text { Jumlah penilai } \\
\sum Y & =\text { Jumlah skor tiap buku petunjuk praktikum }
\end{array}
$$

5) Mengubah skor rata-rata buku petunjuk praktikum yang berupa data kuantitatif menjadi data kualitatif dengan ketentuan pada Tabel 3 [6] sebagai berikut. 
TABEL 3

Kriteria Kategori Penilaian Buku PetunJuk Praktikum

\begin{tabular}{ccc}
\hline No. & Rentang Skor (i) Kuantitatif & Kategori Kualitatif \\
\hline 1. & $\bar{Y}>\left(M_{i}+1,5 S B_{i}\right)$ & Sangat Baik \\
2. & $\left(M_{i}+0,5 S B_{i}\right)<\bar{Y} \leq\left(M_{i}+1,5 S B_{i}\right)$ & Baik \\
3. & $\left(M_{i}-0,5 S B_{i}\right)<\bar{Y} \leq\left(M_{i}+0,5 S B_{i}\right)$ & Cukup \\
4. & $\left(M-1,5 S B_{i}\right)<\bar{Y} \leq\left(M_{i}-0,5 S B_{i}\right)$ & Kurang \\
5 & $\bar{Y} \leq\left(M_{i}-1,5 S B_{i}\right)$ & Sangat Kurang \\
\hline
\end{tabular}

6) Menentukan nilai keseluruhan buku petunjuk praktikum IPA berbasis POE dengan menghitung skor rata-rata seluruh kriteria penilaian, kemudian diubah menjadi nilai kualitatif sesuaidengan kriteria kategori penilaian ideal.

Skor tersebut merupakan kualitas dari buku petunjuk praktikum IPA berbasis model pembelajaran POE yang telah dikembangkan. Nilai yang diperoleh dari tiap praktikum kemudian digunakan sebagai dasar untuk melakukan revisi buku. Kualitas buku petunjuk praktikum dengan rentang kriteria penilaian Sangat Baik (SB) hingga Cukup (C) dianggap layak untuk digunakan dalam proses pembelajaran. Sedangkan kualitas dengan rentang kriteria Kurang (K) hingga (SK) dianggap tidak layak untuk digunakan dalam proses pembelajaran.

\section{HASIL DAN PEMBAHASAN}

Hasil akhir dari penelitian pengembangan ini adalah tersusunnya buku petunjuk praktikum IPA berbasis model pembelajaran POE pada materi usaha dan energi kelas VIII SMP yang telah mengalami beberapa kali revisi. Buku petunjuk praktikum IPA berbas is model pembelajaran POE ini terdiri dari tiga kegiatan praktikum yakni, praktikum energi potensial, energi kinetik, dan perubahan energi.

Buku petunjuk praktikum IPA berbasis model pembelajaran POE pada materi usaha dan energi ini terdiri dari beberapa komponen seperti halaman judul buku, kata pengantar, daftar isi, tujuan praktikum, alat dan bahan, landasan teori, kotak coba cari tahu, kotak prediksi, kotak 'tahukah kamu?', langkah kerja, tabel pengamatan, kegiatan kesimpulan, dan latihan soal.

Buku petunjuk praktikum IPA berbasis model pembelajaran POE memperoleh skor rata-rata sebesar 102 dengan kualitas Sangat Baik (SB) berdasarkan penilaian guru IPA kelas VIII SMP. Grafik skor rata-rata kualitas buku petunjuk praktikum IPA berbasis POE tiap aspek disajikan pada Gambar 1 sebagaiberikut.

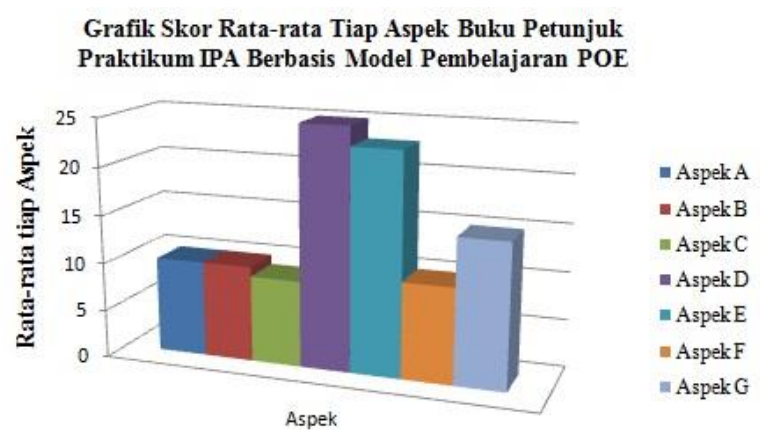

Gambar 1 Grafik Skor Rata-rata Tiap Aspek

Keterangan:

A = Cakupan Materi (Skor ideal 10)

$\mathrm{B}=$ Akurasi Materi (Skor ideal 10)

C = Memacu Keingintahuan (Skor ideal 10)

$\mathrm{D}=$ Penyajian (Skor ideal 25)

$\mathrm{E}=$ Tampilan Umum (Skor ideal 25)

$\mathrm{F}=$ Bahasa dan Keterbacaan (Skor ideal 10)

$\mathrm{G}=$ Penerapan POE (Skor ideal 15)

Aspek cakupan materi buku petunjuk praktikum (Aspek A) memperoleh rata-rata 10 dengan kriteria sangat baik. Aspek A memiliki dua kriteria, yakni: (1) Materi yang disampaikan sesuai dengan standari isi, dan (2) Kesesuaian penyampaian materi dengan perkembangan kognitif siswa. Buku petunjuk praktikum IPA berbasis model pembelajaran POE disusun sesuai dengan standar isi yang berlaku dan dibuat sesuai degan perkembangan kognitif siswa, sehingga buku petunjuk ini mudah untuk dipahami.

Aspek akurasi materi (Aspek B) me mperoleh skor rata-rata sebesar 10 dengan kriteria Sangat Baik (SB). Aspek B terdiri dari dua kriteria, yakni: (1) Kesesuaian materi dengan buku ajar, dan (2) Soal latihan mendukung konsep dengan benar. Penyusunan buku petunjuk praktikum IPA berbasis model pembelajaran POE menggunakan beberapa referensi buku ajar yang digunakan oleh guru agar sesuai dengan apa yang telah didapat oleh siswa. Tiap akhir kegiatan praktikum juga dilengkapi dengan latihan soal yang sesuai dengan konsep sehingga memperkuat konsep yang telah diketahui oleh siswa.

Aspek me macu keingintahuan (Aspek C) memperoleh skor rata-rata 9 dengan kriteria Sangat Baik (SB). Aspek C juga terdiri dari dua kriteria, yakni: (1) Memacu siswa untuk 


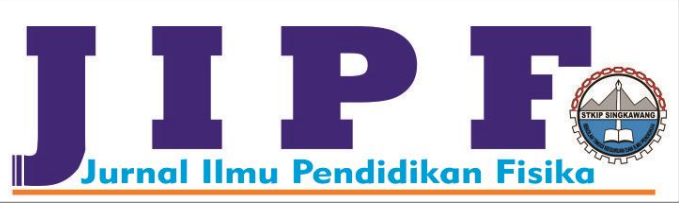

mencari tahu, dan (2) Menekankan pengalaman langsung siswa. Buku petunjuk praktikum berisi tentang fenomena yang biasa disaksikan siswa dalam kehidupan sehari-hari sehingga memacu keingintahuan siswa untuk membuktikan kebenaran konsep yang selama ini mereka yakini mengenai fenomena ters ebut.

Aspek Penyajian (D) memperoleh skor rata-rata 25 dengan kriteria Sangat Baik (SB). Aspek B terd iri dari empat kriteria, yakni: (1) Ilustrasi dan gambar yang disajikan mendukung materi, (2) Memiliki daftar isi, (3) Memiliki identitas atau keterangan gambar dan tabel, dan (4) Informasi yang disajikan menarik dan mudah dipahami. Buku petunjuk praktikum IPA berbasis model pembelajaran POE menyajikan ilustrasi yang disesuaikan dengan materi yang disampaikan agar mempermudah siswa dalam memahami konsep. Setiap gambar dan tabel juga diberi keterangan agar me mbantu siswa memahami hubungan antara gambar yang disajikan dengan materi yang diberikan. Selain itu, dipilih materi yang menarik agar siswa tertarik untuk membaca buku petunjuk praktikum IPA berbasis model pembelajaran POE tersebut.

Aspek tampilan umum (E) memperoleh skor rata-rata sebesar 23 dengan kriteria Sangat Baik (SB). Aspek E terdiri dari lima kriteria, yakni: (1) Halaman lengkap dan berurutan, (2) Cetakan gambar dan tulisan jelas, (3) Tata letak penemapatan gambar dan informasi, (4) Cover tampilan menarik, dan (5) Gambar-gambar yang disajikan menarik. Halaman dalam buku petunjuk praktikum dibuat berurutan sehingga tidak membingungkan siswa ketika melaksanakan praktiku m. Gambar dan tulis an dibuat je las sehingga tidak ada kekeliruan antara gambar dan informasi yang disajikan. Cover dibuat sederhana, tapi cukup untuk menarik minat siswa untuk me mbacanya, dan gambar-gambar yang dipilih akan membuat siswa tertarik untuk membaca informasi hingga tuntas.

Aspek bahasa dan keterbacaan (Aspek F) me mperoleh skor rata-rata 10 dengan kriteria Sangat Baik (SB). Aspek F terdiri dari dua kriteria, yakni: (1) Bahasa yang digunakan sesuai dengan perkembangan siswa, dan (2) Petunjuk mengerjakan soal jelas. Bahasa yang digunakan dalam buku petunjuk praktikum IPA berbasis model pembelajaran POE dibuat sesederhana mungkin untuk membuat siswa memahami dengan mudah maksud yang disampaikan pada buku petunjuk praktikum. Petunjuk soal yang digunakan juga dibuat sejelas mungkin agar sis wa mampu mengerjakannya secara mandiri.

Aspek penerapan POE (Aspek G) memperoleh skor ratarata sebesar 15 dengan kriteria Sangat Baik (SB). Aspek G terdiri dari tiga kriteria, yakni: (1) menyajikan kegiatan prediksi, (2) Menyajikan kegiatan observasi atau penggalian informasi pada kegiatan yang disajikan, dan (3) Menyajikan kegiatan penarikan kesimpulan yang dilakukan oleh siswa. Setelah diberi suatu fenomena yang terjadi di sekitar mereka, siswa akan diminta untuk memprediksi hal-hal yang terkait dengan fenomena tersebut yang kemudian dituliskan pada kotak prediksi yang telah disediakan. Selama proses praktikum, siswa juga diminta mengobservasi apa saja yang telah terjadi selama jalannya praktikum. Kegiatan praktikum diakhiri dengan penarikan kesimpulan oleh siswa, yang kemudian disampaikan di depan kelas .
Penarikan respon dari buku petunjuk praktikum IPA berbasis model POE pada materi usaha dan energi kelas VIII SMP dilakukan dalam dua tahap. Tahap pertama yaitu uji coba skala kecil yang dilakukan pada enam orang siswa dari masing-masing sekolah. Sedangkan tahap berikutnya yakni,uji coba skala luas dilakukan oleh 40 orang siswa kelas VIII dari SMP Negeri 8 Singkawang, dan SMP Torsina 1 Singkawang, masing-masing 20 siswa. Respon dilakukan dengan cara mengisi lembar berbentuk check list respon siswa terhadap buku petunjuk praktiku m IPA berbas is POE pada materi usaha dan energi kelas VIII di kota Singkawang.

Lembar respon terdiri dari delapan kriteria penilaian. Hasil penilaian dalam bentuk data kualitatif kemudian ditabulasi dan dianalisis untuk menentukan kualitas dari buku petunjuk praktikum IPA berbasis model pembelajaran POE yang dihasilkan.

Setelah melakukan uji coba skala kecil yang memiliki hasil Baik (B), kemudian dilanjutkan pada uji coba skala luas. Skor tertinggi terhadap buku petunjuk praktikum IPA berbasis model pembelajaran POE diperoleh dari respon siswa kelas VIII SMP Negeri 8 Singkawang sebesar 72,30 dengan kriteria Sangat Baik (SB), sedangkan dari SMP Torsina, skor yang diperoleh sebesar 66,95.

Skor akhir yang diperoleh dari buku petunjuk praktikum IPA berbasis model pembelajaran POE $(\bar{Y})$ yang telah dikembangkan, yaitu sebesar 68,20. Berdasarkan kriteria penilaian ideal, maka buku petunjuk praktikum IPA berbasis POE yang telah dikembangkan mempunyai kualitas Sangat Baik (SB) menurut respon oleh 40 siswa kelas VIII SMP.

Adapun grafik skor rata-rata penilaian kualitas buku petunjuk praktikum IPA berbasis model pembelajaran POE ditampilkan pada gambar 2 sebagaiberikut.

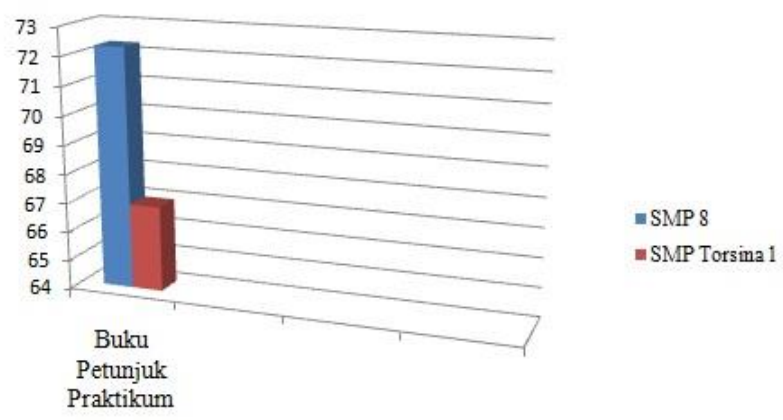

Gambar 2 Grafik Skor Rata-rataPenilaian Kualitas Buku Petunjuk Praktikum IPA Berbasis Model Pembelajaran POE

Skor tertinggi didapat dari responden kelas VIII SMP Negeri 8 Singkawang. Praktikum yang disajikan akan membiasakan sis wa terhadap tiga langkah utama ilmiah, yakni memprediksi, mengobservasi, dan menyampaikan. Berdasarkan hal tersebut, maka buku petunjuk praktikum ini dibuat berlandaskan model pembelajaran POE. Kegiatan praktikum ini melibatkan siswa secara aktif selama proses pembelajaran berlangsung. Hal ini akan membuat siswa memahami konsep yang benar. Selain itu, siswa juga akan mengerti ketika terjadinya perubahan dari konsep yang salah 


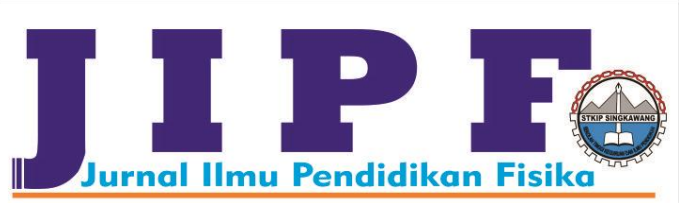

menjadi konsep yang benar. Selain itu, kegiatan praktikum yang disajikan sangat berhubungan dekat dengan kehidupan sis wa sehari-hari sehingga sesuai digunakan untuk KTSP.

Secara umum, penampilan buku yang sederhana mampu mendorong minat siswa untuk me mbaca karena buku petunjuk praktikun yang dikembangkan tidak hanya berisi kumpulan kegiatan praktikum, tapi juga informasi-informasi lain sebagai pengetahuan tambahan bagi siswa. Langkah kegiatan praktikum juga menggunakan bahasa yang mudah dipahami oleh siswa sehingga siswa dapat melaku kan praktikum secara mandiri. Penampilan buku yang didesain penuh warna dan disertai gambar-gambar yang berkaitan dengan kegiatan praktiku m, sehigga sis wa diharapkan antusias untuk me mbaca dan mempelajarinya.

\section{KESIMPULAN}

Kesimpulan umum yang dapat ditarik dari penelitian pengembangan ini adalah buku petunjuk praktikum IPA berbasis model pembelajaran POE dapat dikembangkan dan digunakan dalam proses pembelajaran. Adapun beberapa kesimpulan yang dapat dijabarkan secara spesifik dari penelitian ini adalah sebagai berikut, (1) Telah dihasilkan buku petunjuk praktikum IPA berbasis model pembelajaran POE pada materi usaha dan energi kelas VIII SMP kota Singkawang yang telah dikembangkan dengan menggunakan model pengembangan prosedural, yang direvisi berdasarkan masukan dari ahli materi, ahli media, dan guru, (2) Kualitas buku petunjuk praktikum yang dinilai oleh dua guru IPA kelas VIII yang masing-masing berasal dari SMP Negeri 8 Singkawang dan SMP Torsina 1 Singkawang adalah sangat baik, dengan skor 102, sehingga buku petunjuk praktiku m IPA berbasis POE, layak untuk digunakan oleh guru sebagai bahan ajar di sekolah, (3) Kualitas buku petunjuk praktikum yang dinilai berdasarkan respon 12 orang siswa pada uji coba skala kecil sebesar 67,66 dengan kriteria Baik (B). Sedangkan pada uji coba skala luas yang dilakukan pada 40 siswa yang berasal dari SMP Negeri 8 Singkawang dan SMP Torsina 1 Singkawang, dengan rincian 20 siswa dari SMP Negeri 8 Singkawang, 20 orang dari SMP Torsina 1 Singkawang adalah Sangat Baik (SB), dengan skor 68,20 sehingga buku petunjuk praktikum IPA berbasis POE dapat digunakan oleh sis wa sebagai tambahan sumber.

\section{DAFT AR PUST AKA}

[1] Rosdianto, H., \& Toifur, M. (2017). Implementasi Teori Distribusi Probabilitas Gaussian Pada Kualitas Rangkaian Penyearah Gelombang Penuh. SPEKTRA: Jurnal Fisika dan Aplikasinya, 2(1), 83-90.

[2] Yupani, N.P.E., Garminah, N.N., \& Mahadewi, L.P.P. (2013). Pengaruh Model Pembelajaran Predict-ObserveExplain (POE) Berbantuan Materi Bermuatan Kearifan Lokal terhadap Hasil Belajar IPA Siswa Kelas IV. Jurnal Mimbar PGSD, 1, 1-12.

[3] Rosdianto, H. (2017). Penentuan Percepatan Gravitasi Pada Percobaan Gerak Jatuh Bebas Dengan Memanfaatkan Rangkaian Relai. SPEKTRA: Jurnal Fisika dan Aplikasinya, 2(2), 107-112.
Jurnal Ilmu Pendidikan Fisika

Volume 3 Number 1 month March 2018. Page 14-19 p-ISSN: 2477-5959 e-ISSN: 2477-8451

[4] Suparno, P. (2013). Metodologi Pembelajaran Fisika Konstruktivistik \& Menyenangkan (Edisi Revisi). Yogyakarta: Penerbit USD.

[5] Sugiyono. (2014). Metode Penelitian Pendidikan Pendekatan Kuantitatif, Kualitatif, dan $R \& D$. Cetakan kedua puluh. Bandung: ALFABETA.

[6] Farikhayati (2009). Pengembangan Buku Petunjuk Praktikum Kimia Untuk SMP/MTs Kelas VII Berdasarkan Kurikulum Tingkat Satuan Pendidikan (KTSP). Skripsi S1, Program Studi Pendidikan Kimia Fakultas Sains dan Teknologi UIN Sunan Kalijaga. Yogyakarta. 